\title{
Study Registry Document
}

National Cancer Institute

\section{Source}

National Cancer Institute. Study Registry Document. NCI Thesaurus. Code C115734.

Records pertaining to the registration of a clinical trial in public registries, like

ClinicalT rials.gov, and used for submission of results, both during the study, and at its completion. 